\title{
Making Space in Brasília: Cultural Texts from 2009 to 2014
}

\section{Sophia Beal}

University of Minnesota, Twin Cities

\begin{abstract}
In learning about Brasília, we learn about the power of place, not as deriving from some static, unchanging location, but from the dynamic negotiations that unfold there. Drawing on theory related to social space and cultural geography, particularly that of Henri Lefebvre and Doreen Massey, this study analyzes music, music videos, creative nonfiction, and poetry concerned with the negotiations that imbue the city with meaning. Five of Brasília's contemporary cultural texts (created by Nicolas Behr, Ellen Oléria, Viela 17, Sexy Fi, and Augusto Rodrigues from 2009 to 2014) illustrate the spatial negotiations that shape the subjectivities of Brasília’s residents.
\end{abstract}

Keywords: Power, Place, Brazil, Music, Literature

Most research on the intersections of contemporary cultural production and urban space in Brazil focuses on the cities of São Paulo and Rio de Janeiro. ${ }^{1}$ Brasília often is overlooked in these analyses because it is associated more strongly with politics than with artistic production. Moreover, the capital's architecture and design are so emblematic of the late 1950s and early 1960s that critics tend to view Brasília as a living museum and modernist icon more than a city where art continues to be made. However, art does continue to be made. And, Brasília's art-especially music and literature-is being made in ways that are intriguingly bound up with spatial relations.

Five of Brasilia's contemporary cultural texts shed light on the spatial negotiations that continuously transform the city and shape the subjectivities 
of its residents. The first is plant specialist and poet Nicolas Behr's book of vignettes about Brasília, BrasíliA-Z: cidade palavra (2014). Behr registers the negotiations among people and trees, denaturalizing the city's green space by showing the extent to which it is the product of individuals' choices. The second is Ellen Oléria’s song "Senzala (a feira da Ceilândia)," on her debut album Peça (2009), a fusion of soul, funk, and hip hop, recorded with her band Pret.utu. Oléria showcases the way in which negotiations related to race, class, and gender affect how people circulate within the city. Third is 1990s-style rap group Viela 17's single "20 de 40" and the song's music video, both released in 2012. The video for " 20 de 40 " presents Ceilândia, where current blight can be understood as the result of top-down planning that has left little room for residents to negotiate for better living conditions. The fourth is indie rock band Sexy Fi's 2012 debut album Nunca te vi de boa and its first music video, for the song "Pequeno dicionário das ruas." In Sexy Fi’s music and video, adolescents growing up on the large residential blocks known as superquadras negotiate their living environment in ways that shape their subjectivities. Fifth is Augusto Rodrigues's third poetry collection Do livro de carne (brasílias invisiveis), published in 2011. It integrates the actual layout of the Plano Piloto (Lucio Costa's original plan for the city, known for its airplane shape) and more fantastical poetic representations of it. The negotiation between real and imaginary makes for startling poems that, in turn, highlight the defamiliarizing effect of the actual Plano Piloto. In learning about Brasília through these texts, we discover how the city is the product of the continuous negotiations that unfold there.

These varied texts, which invoke considerations of race, gender, class, and genre, expose the messiness and multiplicity of contemporary Brasília. The work of philosopher Henri Lefebvre and geographer Doreen Massey helps us to understand more fully that messiness and multiplicity. Lefebvre, with his publication of La production de lespace in 1974, nuanced our appreciation of the complexity of space, shifting attention to how space is used and how it is both the product and the producer of social relations. In the twenty-first century, Massey calls for the need to understand material spatiality as the product of heterogeneity and interaction, paying attention to the various trajectories that cross in a given location, an argument influenced by and influential to contemporary cultural geography (94). 
Space in Brasília rarely is straightforward. Slippage of meaning is common because a subject's location may alter the meaning of words such as Brasilia, city, and center. The term Brasilia can refer to two geographical regions. The first is an administrative region of the Federal District that roughly includes the Plano Piloto and the National Park of Brasília. The administrative region Brasília has a population of about 215,000 and an area of about 470 square kilometers. The second is the entire Federal District, one of Brazil's 27 federative units (the other 26 of which are states) with a population of 2.8 million and an area of about 5,780 square kilometers. The Federal District is divided into 31 administrative regions, each governed by a regional administrator with power equivalent to that of a mayor. Ceilândia, with a population of 398,000 (a bit larger than Cleveland, $\mathrm{OH}$ ), is the most populous administrative region, and 11 of the administrative regions have populations of over 100,000. Due to their political structure and population size, it is not uncommon to refer to an individual administrative region as a city; however the word city also is commonly used to refer to the entire Federal District. For instance, the Brazilian Institute of Geography and Statistics ranked Brasília (referring to the entire Federal District) as the fourth most populous city in the nation in 2010, noting that in Brazil a city is the headquarters of a municipality and that the Federal District has no municipalities, yet can be treated as a city due to its urban aspects. In the present essay, I use the terms Brasilia, capital, and city to refer to the Federal District, using the terms interchangeably. Some of the texts analyzed focus on the Plano Piloto, which remains the center of power, not just legislative and economic, but also symbolic. It is the dominant image of the Federal District and a designated UNESCO World Heritage Site.

Brasília's noteworthy history has marked the city both as an aesthetic wonder and a social conundrum. In 1956, President Juscelino Kubitschek declared that a new capital would be built at Brazil's center, linking otherwise disconnected regions symbolically and physically via new roads fanning from Brasília. Lucio Costa won the design competition with his airplane-shaped layout, which elicited hope, advancement, and Brazil's growing airplane manufacturing industry. Oscar Niemeyer designed palaces whose modern elegance derived from their clean lines, lack of adornment, and surprising curves. Niemeyer used 
prefabricated materials that made the ministries quick to assemble and easily reproducible. Walls of Athos Bulcão's mosaics tile the city with contrasting bright colors. Together, these founding fathers of Brasília created the most ambitious modernist design project of all time. Although Brasília is acclaimed as an aesthetic project, Costa's attempts to create more egalitarian living conditions failed for various reasons. Construction workers the government had anticipated would return home chose to stay. The population far surpassed predictions. The logic of capitalism trumped the socialist intentions of the residential model. The 1950s model of a city built for car owners clashed with more contemporary urban design models and with many residents' inability to afford a car. And the poor were pushed considerably further from the center than in most cities due to a green belt of agricultural and park land. An excellent body of scholarship examines Brasilia, and it focuses on the types of social exclusion facilitated by the city's design. ${ }^{2}$ However, with the exception of studies about Brasilia's rock music (particularly the band Legião Urbana) and, to a lesser extent, the novels of João Almino, little has been written about the music and literature of Brazil's capital, especially recent contributions. The subsequent close analyses, beginning with Nicolas Behr's BrasiliA-Z: cidade-palavra, attempt to fill that gap.

\section{Nicolas Behr: BrasíliA-Z: cidade-palavra}

Behr's 2014 BrasiliA-Z: cidade-palavra is a mixture of guidebook (comprised of alphabetically arranged vignettes), personal and cultural history, and anthology of song, poems, and photographs of Brasília. He cultivates saplings and vivaria for a living (as well as being the Federal District's most famous living poet), so it comes as no surprise that BrasiliA- $Z$ presents the influence of flora on the city, a focus rare in Brasília’s literature. Geographer Edward Soja notes that "space in itself may be primordially given, but the organization, and meaning of space is a product of social translation, transformation, and experience" (79-80). In Brasilia- $Z$, the types of social translation, transformation, and (personal) experience that organize Brasília and make it meaningful are the negotiations among people and vegetation. Behr presents Brasília as the product of negotiations involving trees, officials, and individuals in such a way as to denaturalize the Federal District's landscape. 
A common misconception about Brasilia is that the cerrado-the tropical savanna eco-region in which it was built-was empty, a tabula rasa befitting a modernist masterpiece: "Abra qualquer publicação sobre o começo de Brasília que lá vai estar: isso aqui era um deserto; a cidade chegou e não havia nada; era um vazio sem fim; um cerrado sem vida" (BrasíliA-Z 36). Like João Guimarães Rosa's 1962 short story "As margens da alegria," BrasíliA-Z makes clear what had to be destroyed in order to create the capital. The entry "Cerrado" in BrasiliA- $Z$ laments that large swaths of savanna were unnecessarily razed during the construction of the capital, in part, due to the cerrado's inferior status: "o cerrado, naqueles tempos, era (e para muitos ainda é) o patinho feio da vegetação brasileira, um bioma de segunda classe" (36). Moreover, Behr balks at how promotional material published at Brasília’s inception falsely claimed that "depois de construída, a cidade tem mais árvores do que antes” (36). Such materials are less of a lie than evidence that the cerrado's native trees were not considered trees at all. In a country in which an avenue of gigantic imperial palms and the world's largest cashew tree are tourist attractions, the cerrado's mid-size trees with tangled branches could not compete.

Behr's concern that the cerrado is both underappreciated and threatened by irresponsible agricultural practices echoes in his short joke-poem "Nem tudo" (from his 1993 collection Beijo de hiena), included in the guidebook:

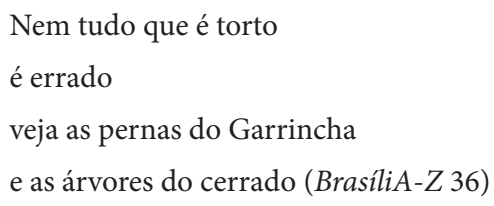

Despite the destruction of native trees, the Federal District boasted 985 square meters of green space per capita in 2010, the second highest (behind Quito) in a comparison of 30 major Latin American cities (Economist Intelligence Unit 16). However, as Behr underscores, this investment in green space is unevenly distributed. In 2003, Novacap invested ten times more money (2 billion Reals) to maintain the green space of the Plano Piloto than it spent maintaining the green space of all the satellite cities combined, which occupy ten times more 
surface area (Gouvêa "A violência estrutural" 348). Behr calls for "cidades-satélites mais arborizadas e com mais áreas de lazer," exposing a starkly uneven distribution of that green space and presenting vegetation as something not primordial, but political and planned (22).

Behr recounts that, at present, there are 15,187 trees in the Plano Piloto, and that the most common type is the mango tree (98). The prevalence of mango trees is explained as the result of individuals illicitly modifying plant life: "Burlando o paisagismo oficial, se veem muito, nas entrequadras e na Esplanada [dos Ministérios], pés de mangueiras, jaqueiras, abacateiros e outras frutíferas, plantadas principalmente pelos vigias e porteiros" (84). This tendency is, to use Michel de Certeau's term, a tactical reappropriation of space. ${ }^{3}$ Those with desires to attract birds, grow fruit, and beautify their neighborhoods outmaneuver Novacap's request that individuals do not plant trees in public areas. ${ }^{4}$

Other entries in the guidebook elucidate more intimate, emotional instances of how Brasília becomes meaningful to the poet via its vegetation. Behr lists the 14 species of palms native to the Federal District, and his taxonomy is less pedagogical than it is sensory. To borrow a concept from Heidegger, it "brings the presence of what was previously uncalled into a nearness" (198). Bringing together ideas from Heidegger's Poetry, Language, Thought and Deleuze and Guatarri's What is Philosophy?, Sten Pultz Moslund reflects on how words in poems can elicit a sensory response:

Precisely because naming things brings things forth or close, as if standing
them up before our senses, the word opens toward a prelinguistic sensation
that compares with the sensation of the thing itself. This is not a mimetic copy
or a true reflection of the object of the thing-world but a triggering of the sen-
sations of that object-as when art, in Deleuze and Guatarri's terminology,
brings before us "not the resemblance but the pure sensation" of an object. (32)

Moslund's point helps uncover how Behr's text is more bound up with sensation than meaning. Behr divulges that "me emociono" each time he sees the half-century-old "living wall" (cerca-viva) of Plathymenia trees (vinháticos) planted by botanist Ezechias Paulo Heringer in the 1960s in front of the 
Estação Experimental de Biologia at the University of Brasília (158). At a time when so many trees in the area were being cut down to build the new capital, these were thoughtfully planted.

Behr underlines how Brasília’s vegetation continuously transforms. His arboreal references thus reinforce the following argument made by Massey: "Instead of things as pregiven discrete entities, there is now a move towards recognising the continuous becoming which is in the nature of their being. Newness, then, and creativity, is an essential characteristic of temporality" (20-21). I would like to close this section with a brief reflection on how Behr's interest in the continuous becoming of Brasília also is found in contemporary photography. Photographs by Brasília-based photojournalist Zuleika de Sousa (her Instagram photographs from 2015 and earlier years) and Dutch photographer Iwan Baan (his series "Brasília” from 2010) — via images of darkening concrete, budding trees, and people moving about-evoke how flora, humans, and building materials evolve at different rates within the same location. These texts and images reinforce how space "is always being made" (Massey 39). Moreover, for Behr, the plants within this changing landscape elicit emotion, appearing as something that should be cultivated, fought for, reflected upon, and protected. Shifting away from negotiations between people and vegetation, the following sections examine social negotiations within the capital.

\section{Ellen Oléria: "Senzala (a feira da Ceilândia)"}

Lefebvre argues that sociopolitical conflicts, since they take place in space also become conflicts of space (365). Lefebvre thus allows us to see how negotiations for space are interrelated with income, race, and residence. Oléria's song "Senzala (a feira da Ceilândia)" elaborates the social contradictions of space in Brasília.

Oléria describes her music in spatial and identitarian terms: "Canto o universo de uma negra, lésbica, criada na Chaparral, região entre Taguatinga e Ceilândia" (qtd in Lima). In Oléria’s song "Senzala," on her 2009 album Peça, space matters. The location of the song's subject (the $I$ in the lyrics) is unstated, but she is headed to the Feira da Ceilândia, which gains meaning via its contrast to the Plano Piloto. The song treats the Feira da Ceilândia-one of the Federal District's largest open-air markets-with ambivalence. It appears as a 
space of overflowing materialism where the forces of advertising and the beauty industry (Brazil is the third-largest cosmetic market in the world) as well as the sociality of the fairgrounds threaten women's virginity, sense of self, and values.

The feminist and anti-materialist lyrics are complicated by the upbeat tone, eclectic ensemble (voice, drums, bass, guitar, keyboard, saxophone, trumpet, trombone, triangle, bass drum, and accordion), and shifts in musical style that approximate the excess, noise, and crowdedness of the fair in a more celebratory way than the lyrics. Wordplay conflates consumption and happiness: "o cinto da moda, o sinto da moda." Then the song shifts to lofty goals that trump material acquisition:

\footnotetext{
Mas o que você precisa mais, na feira não se pode encontrar:

razão, consciência, senso, inteligência, uma cabeça pra pensar.
}

Yet that message ironically is undermined by what follows, the first and only reference to the Plano Piloto:
Isso só no shopping lá do centro você vai achar,
se tiver dinheiro pra comprar,
boa aparência pra entrar.

Despite Ceilândia being its own administrative region with its own center, the song uses the term centro to refer to a location beyond the bounds of Ceilândia: the Plano Piloto, which dominates economically, symbolically, and artistically as the epicenter. Reason, conscience, judgment, and intelligence are for sale in the Plano Piloto, a metaphor evoking the spatial distribution of cultural capital.

The Plano Piloto is the casa grande to the song title's senzala, highlighting how colonial Brazilian sugar plantations were segregated spatially and racially and how the repercussions of those divisions continue to echo in contemporary socioeconomic configurations. ${ }^{5}$ Not far from the Feira da Ceilândia, for instance, is the Feira do Rolo, an open-air market where used and stolen goods are sold. Later in the afternoon, the same location becomes a zone for 
prostitution, known for including sex workers who are minors. Oléria's use of the word senzala upends notions of a single, always-improving historical trajectory by unveiling colonial and neocolonial power structures and how they are reinforced by everyday spatial practices. Not only does Ceilândia gain meaning in comparison to the far-off lá of the centro, but also that center has a powerful affective influence on the subject, as the last quotation demonstrates: she feels unwelcome there as a consumer.

The song rejects the shopping mall, an icon of the privatized, generic, exclusive space associated with neoliberal cities and with Marc Augés nonplaces. However, it does so without idealizing the Feira da Ceilândia as a fixed, quintessentially local public space of equality. ${ }^{6}$ Lines such as "mulheres [...] esbanjem no batom," "lá tem pastel e tem caldo de cana," "vamos copiar desde filme Titanic a sanduíche," and "virgindade lá é coisa do passado" expose a mixture of global and local forces, the power of consumer capitalism, and gendered marketing strategies.

What stands out most is the familiarity of the fairgrounds to the subject. She has been there before. She positions the periphery at the center, and her lyrics suggest that the heart of Brasília’s music is also located in the periphery, blasted through loudspeakers at its fairs:

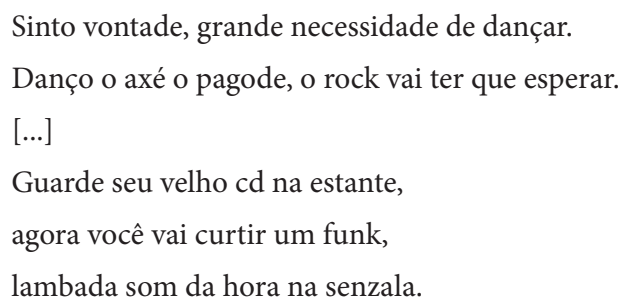

In the 1980s and early 1990s, Brasília was the hub of the country's rock music scene, the first Brasília cultural movement to gain national recognition. Its most well-known bands (Aborto Elétrico, Plebe Rude, Capital Inicial, Legião Urbana, and Os Paralamas do Sucesso) comprised the so-called Turma da Colina, named for the residential part of the University of Brasília where these young, affluent musicians lived and socialized. As their nickname suggests, 
Brasília’s rock scene gravitated around the Plano Piloto. Oléria’s line "o rock vai ter que esperar" declares that Rock Brasília has now been outdone by other genres, hailing from other parts of the city and often influenced by the culture of Brazil's northeast, the native region of many of Ceilândia's residents. Oléria's national success as a singer who fuses various genres registers an enthusiasm for these new types of sound being produced in Brasília. I turn next to one of the most celebrated genres of Brasília’s contemporary music: hip-hop.

\section{Viela 17: "20 de 40"}

Brazilian hip-hop, as anthropologist Derek Pardue stresses, is concerned with spatial transformation. ${ }^{7}$ Pardue notes how Brazilian hip-hop artists portray their working-class, urban communities as the "fault lines of a system spatially grounded in a set of exclusive real estate practices" (Ideologies 170). Pardue underscores that Brazilian hip-hop artists share a goal to "conquistar um espaço" via cultural and educational initiatives that are part of a social investment in Brazil's urban periphery (“Conquistando Espaço"” 221). This preoccupation with space is apparent in the very name of hip-hop group Viela 17. It refers to a street in Ceilândia where hip-hop has flourished. The group’s 2012 song "20 de 40 " reflects on the 20-year music career of its then 40-year-old leader, Japão, a career deeply connected to Ceilândia, as the song's music video reveals.

The video opens with a clip from an authentic government video from 1971 in which a voiceover accompanies footage of Ceilândia, exhibiting functional public services: a bus, orderly rows of public housing, electrical lines, and running water. The narrator boasts that the Federal District Government, the Secretary of Social Services, and the Campaign for Squatter Eradication "conseguiram extinguir aquele aglomerado humano"-referring to the informal camps of former construction workers-in order to create Ceilândia. It is described as a "solução social pioneira na América do Sul."

Lefebvre argues that spaces produced to be interpreted are the most deceptive because they give the impression of being decipherable, while concealing "strategic intentions and actions" (143). The government video, by casting Ceilândia as a pioneering social solution in South America, dissimulates the expulsion of laborers from more central areas and the problems of 
neighborhoods created for and not by their inhabitants. Brazilian hip-hop often is born from the spatial violence of families and entire communities forced to evacuate, and Viela 17 alludes to this concern (Weller 190-91). ${ }^{8}$

In March of 1971, 80,000 people were relocated to Ceilândia, some 30 kilometers from the center of power. Contrary to the promotional video, most of Ceilândia had no running water or electricity, which caused many people who previously had worked in the informal sector, such as washerwomen, to lose their source of income. Moreover, the lowest income residents were forced to pay daily for the most expensive public transportation system in the country (Gouvêa "A violência estrutural" 347). Housing specialist Luiz Alberto de Campos Gouvêa refers to the "verdadeiro apartheid social que se criou planejadamente em Brasília" ("Habitação e emprego" 233). The ironic placement of the archival footage within a socially engaged hip-hop video reminds us that Ceilândia’s name speaks to that history of systematic segregation: the first three letters stand for Campanha de Erradicação de Invasões.

"20 de 40" features Alex Jordan (leader of the gospel group Dreams Coral) singing the refrain in a melodic, hopeful style, referring to Expansão do Setor O, Japão's neighborhood:

Ceilândia na cena, Viela, expansão
Onde fiz a minha história, meu irmão [...]
As luzes da cidade escura não ofuscam o meu brilho, não.

The group is pledging its spatial allegiances specifically to a street, a neighborhood, and an administrative district. The here in the song is Ceilândia, the geographical unit around which the band's identity is shaped. The treatment of work, violence, drugs, materialism, socializing, dance, music, writing, and sex work in the lyrics and visuals present Ceilândia as a space where simultaneous and varied trajectories cross paths. Moreover, " 20 de 40 " points to problematic ways in which spaces are reappropriated: "Escola é ponto pro olheiro que vende farinha." The end of the credits contains a dedication: "em atenção aos usuários de crack, família [sic] desoladas, e a um futuro incerto, o grupo Viela 17 pede justiça." By inserting the song between archival footage and this call for justice, 
Japão bookends a song about his professional trajectory with Ceilândia's own trajectory, affirming Viela 17's commitment to its community.

Both "Senzala" and " 20 de 40 " put the periphery at the center, thus destabilizing the Plano Piloto's central status. In the case of Viela 17, this reminds us that the rap center of the Federal District is, indeed, the periphery. As Behr's lists of palm species recall the Heideggerian concept of conjuring the existence of something by calling its name and, thus, bringing it near, something similar happens in Viela 17's song via local slang and spatial references. ${ }^{9}$ Viela 17 emphasizes a spatial shift in which the periphery (often referred to as such), not the Plano Piloto, is a site of musical production and dignity, even amid inadequate basic services.

At the other end of the spectrum, Sexy Fi, the subject of the next section, registers the life of affluent residents of the Plano Piloto. Despite their differences, both Viela 17 and Sexy Fi share a common interest in the types of social negotiations that make their slice of the Federal District personally meaningful.

\section{Sexy Fi: Nunca te vi de boa}

Sexy Fi's Nunca te vi de boa and Augusto Rodrigues's Do livro de carne foreground a spatial element unique to Brasília’s Plano Piloto: superquadras. To appreciate these cultural texts requires a brief introduction to the superquadra. Designed by Lucio Costa, superquadras are 280 square-meter residential blocks, each of which contains about ten six-story apartment buildings. Ample green space surrounds the buildings, and their low height facilitates communication and a sense of closeness, as one can yell down from a sixth-floor window and be heard by a person below. No fences or walls line the superquadra's perimeter, adding to a sense of openness uncharacteristic of wealthy residential areas in urban Brazil. Influenced by Le Corbusier, the apartment buildings are raised on reinforced concrete pilotis, load-bearing columns that allow for more visibility, light, movement, and integration among people, landscape, and architecture. Referring to the effect of this open-air ground floor, Lucio Costa notes, "o acesso flui livremente através dos prédios, apesar dos prédios.” Between superquadras runs an entrequadra, a street with commercial real estate and other services. Although these services were meant to include a school, community 
center, swimming pool, post office, police station, playing field, theater-cinema, and churches-creating a self-sustaining neighborhood in which basic needs were within walking distance-this ideal rarely became a reality. The commercial strip primarily holds shops and restaurants and, increasingly, added apartments. Four superquadras were meant to form a Unidade de Vizinhança (neighborhood). However, the only one that was completed was that comprised of the Asa Sul's superquadras 107, 108, 307, and 308, the neighborhood featured in Sexy Fi's music video for "Pequeno dicionário das ruas."

The album's spatial reference is distinctly the Plano Piloto, where all five band members spent a significant part of their life. ${ }^{10}$ Titles of songs in English and Portuguese ("Plano: pilotis," "Looking Asa Sul, Feeling Asa Norte," and "Roriz 2010") mine the Plano Piloto's layout, lexicon, and political scandals for musical inspiration.

Guitarist João Paulo Praxis highlights the band's desire to share the intimate un-monumental locale of the band members' youth: "As pessoas estão acostumadas com a Brasília grandiosa, dos monumentos, do Congresso, da política. Mas a Brasília do nosso cotidiano, onde crescemos, muitas vezes percorrendo suas avenidas a pé, parece outra cidade" ("Nancy ressuscita"). This is most apparent in the music video for "Pequeno dicionário," which was filmed in superquadras 307 and 308 Sul. While the Federal District's most well-known icons are its palaces, the video depicts Brasília via the smaller, more intimate icons of the superquadra: pilotis, the stick-and-ball game bete, masked bate bola carnival clowns (a Brasília tradition since the 80s), parties within and below a bloco (apartment building), Athos Bulcão's tiles on an exterior wall, and the types of socializing conducive to the superquadra. Cobogós cast their shadows on vocalist Camila Zamith's face, visually reinforcing how the aesthetics of the superquadra influence inhabitants. ${ }^{11}$ The video-driven more by its aesthetics than a political message or narrative-appears as a dreamlike memory of growing up in superquadras at the turn of the twenty-first century. ${ }^{12}$

A comparison between Sexy Fi's video and Viela 17's video has spatial implications. The contrast between the 1971 and 2013 footage in the video for "20 de 40" implies that, despite claiming to be an innovative social solution, urban planning created entropy. The video demonstrates that this dystopian 
space needs to be acknowledged, fought for, and transformed. Hip-hop is part of that process. In contrast, the "Pequeno dicionário" video showcases the superquadra 307 South, the most successful example of Brasília's utopian housing model. It juxtaposes the inviting visuals of the idyllic superquadra with its disaffected youth. A partygoer drinks until he vomits; Zamith stares through the camera expressionless; loneliness and listlessness pervade. The video and the album poke fun at the insularity and angst of this drug-abusing affluent group whose unhappiness is undeterred by the utopian urban planning meant to transform society. We catch a glimpse of life beyond superquadra 307 South in a scene of two crack users who join a crowd following Zamith through a pedestrian underpass. Yet, they are ignored and ignorable by the video's many other characters, due to a spatial insularity unavailable to the characters in Viela 17's video. Although " 20 de 40 " exhibits spatial exclusion and social violence and "Pequeno dicionário" displays the aesthetics and community of the superquadra, both videos fixate on how spatial negotiations form subjectivities.

The spatial negotiations that form subjectivities involve the language and slang terms members of a group use, which help crystalize their sense of belonging to a group or location. The lyrics to "Pequeno dicionário" nonsensically string together a series of slang terms, using them not to convey meaning, but to mark fluctuating aspects of colloquial speech. The same is true of the band name, which adopts the slang word $f$ (from filho) used to refer to a person. While Behr's list of palms places his writing within the cerrado vegetation and Viela 17's slang places it within the Federal District's periphery, the ironic slang in "Pequeno dicionário" places the song within a specific temporality. Moslund, drawing on the work of philosopher Edward Casey, observes that spatial references in a text should not be "equated with stasis or finality but with a continual process of reemplacement: changing languages of emplacement are always in the process of getting back into changing physical places" (37). The song's video reinforces this idea as the viewer sees a hand in a superquadra apartment write out shifting slang terms (peixe, véi, fi), suggesting their constant flux and connection to a location and a collective identity.

I would like to close this section with some remarks on how Sexy Fi gives an implicit nod to Niemeyer's belief in the importance of surprise, a subject that 
will be covered in more detail in the next section about poet Augusto Rodrigues. Sexy Fi's album (particularly the songs "Togetherness," "Pequeno dicionário das ruas," "Plano: pilotis," and "Roriz 2010"), like the modernist architecture it references, succeeds by surprising us. For instance, terms such as Le Corbusier (in "Roriz 2010") and pilotis (in "Plano: pilotis") sung in Zamith's hushed voice, when accompanied by distorted guitars and the occasional unexpected clarinet, capture the element of surprise the Plano Piloto's architecture can elicit. Zamith states, "a gente quer assustar. O João Paulo falou isso pra mim no primeiro ensaio da banda. 'Temos que assustar"' (Zamith). This desire is reminiscent of Niemeyer's belief that "na arquitetura, além da sua funcionalidade obrigatória, o importante, a meu ver, é a sensação de surpresa que ela provoca quando, pela sua beleza, atinge o nível da obra de arte" (40). Both Sexy Fi and Augusto Rodrigues continue a Brasília tradition of making art that surprises.

\section{Augusto Rodrigues: Do livro de carne (brasílias invisíveis)}

The experimental format and wordplay of Augusto Rodrigues's 2011 Do livro de carne (brasilias invisíveis) is startling in the same way that being in the Plano Piloto is. However, this discomfort prompts a profound engagement with the city. Brasília’s aesthetic features (curtain walls, pilotis, flat roofs, stark contrasts between vertical and horizontal volumes, dominance of white and natural colors, and cobogós), which are closely connected to Le Corbusier's Five Points of Architecture, constitute a dramatic departure from the aesthetics of other Brazilian cities. Yet, what is more shocking than individual features is the relationship between built and unbuilt spaces. James Holston, in analyzing Brasília, contends that "by asserting the primacy of open space, volumetric clarity, pure form, and geometric abstraction, modernism not only initiates a new vocabulary of form, more radically it inverts the entire mode of perceiving architecture" (133). Most Brazilian cities-and more generally most Western cities-were designed with more solids than voids, following a colonial model of relatively high population density in which street walls lead to articulated public spaces, such as public squares that showcase large figural objects, primarily the structures of Church and State. Beginning in the 1920s, Le Corbusier and the Congrès International d'Architecture Moderne challenged this model, 
seeking ways to open up cities and build vertically to allow for more movement, vegetation, and light. Following this vein-which was influential in the 1950s and early 1960s-Brasília’s Plano Piloto has more voids than solids, creating an expansiveness that is surprising in comparison to other Brazilian cities. The capital's monumental buildings appear as stand-alone objects, disconnected from a larger urban fabric, and the intimacy of superquadras is detached from streets and the familiar sociality that takes place on them. Thus, Brasília's design demands our attention by transforming the way we perceive and interact with a city. Rodrigues replicates that feeling of perplexity and surprise.

The Plano Piloto, now over fifty years old, appears, from certain perspectives, frozen in time. Rodrigues writes, "brasília é a capital do semtempo," expressing this surreal quality of pausing in time ("Paisagem 404"). Suggesting how the original buildings are aging together, the subject asks, "aqui o espaço é igual ao tempo?" ("Paisagem 408"). The uniformity of the architectural style thus creates a peculiar sense of time as having stopped in the 1960s or as causing buildings to age uniformly: "até o tempo é novo em brasília" ("Paisagem 409").

While experimenting with notions of time, Rodrigues also experiments with space, in both the physicality of the actual book and the way the poems approach space. The format of the book references the experience of being within the Plano Piloto. The cover, which looks like a compass, includes Brasília's symbols for the cardinal directions ( $, \mathrm{L}, \mathrm{S}$, and $\mathrm{W}) .{ }^{13}$ Yet the inside cover rearranges the cardinal directions, signaling a break with objective representation. Moreover, the word brasilia appears with a lowercase $b$ in Rodrigues's poetry, hinting that the city within the poems is not meant to be a faithful representation. The use of lowercase letters also alludes to concrete poetry's predilection for the clean uniformity of using only lowercase letters. ${ }^{14}$ Each poem, shaped like a square (the book too is square) and assigned a superquadra address $(408,409 \ldots)$, resembles a superquadra. ${ }^{15}$ The poems concern the affective experience of being in the Plano Piloto and Brasília's artistic identity, as can be gleaned from wordplay and parody related to the city's artists and to canonical authors, which emphasize the literary identity of a city rarely lauded for its writers. ${ }^{16}$ The poems are organized numerically, mimicking the full span of the superquadras in the 400s, which are located on the lakeside of the Eixão 
Highway. At the center of Do livro de carne, the remaining pages are upsidedown, forcing the reader to physically flip the book over to continue reading, thus drawing attention to the book's materiality and its connection to the physicality of the Plano Piloto. However, unlike the actual superquadras, the names of which begin with SQS or SQN to indicate north or south, Rodrigues's book provides no indication of which side is the Asa Sul and which is the Asa Norte. Instead, each poem title serves for two poems (for instance, two poems are titled "Paisagem 409") and the pages are unnumbered, adding to the sense of bewilderment and destabilizing the logic of the city.

Rodrigues's verbal experimentation leaves the reader disoriented: "quando fujo de brasília, amor ardendo, voo para outra cidade: brasília" ("Paisagem 403”). ${ }^{17}$ This line evokes Massey's argument that space is the product of simultaneous trajectories and is constantly in flux. One cannot return to the same Brasília because Brasília is continuously being produced by the interactions that take place there. It is not a fixed container, but a dynamic and contingent entity. Rodrigues writes: "o êxodo de brasília é invertido: as pessoas, quando fogem, vão para cá" ("Paisagem 409"). The reader is startled by the grammatical incorrectness of the phrase. Neither "vêm cá" nor "vão para lâ"; and what might "vão para cá" mean? The question thus replicates the feeling of shock elicited by the Plano Piloto. By creating a nonsensical phrase, the poem also reminds us of the limitations of spatial representation, highlighting how the space cannot, like the phrase, be fully understood.

The line that best encapsulates the book's tone is "e uma vontade de poder" ("Paisagem 412"). It continues a trend in Rodrigues's poetry of referencing Nietzsche, particularly the concept of will to power, to understand the power of place on the imagination by connecting a general force underlying Brasília's structures and a driving force within poets to strive for the highest achievement in their writing. ${ }^{18}$ Moreover, since the line comes directly after "e uma vontade de chorar," the repeated syntax invites us to read poder as a verb also. The line, thus, could signify "a desire to be able to," accentuating an incomplete yearning related to space. In addition, the desire or will is indefinite ( $a$ not the), suggesting a personalized, not generalizable relationship between space and subject. All of the examples in this study expose "uma vontade de 
poder"-linked to their subjects' desire to reveal the types of interactions and negotiations that are unfolding in Brasília.

\section{Conclusion}

The cultural texts that form the focus of the present essay bring together planned space (Costa's Plano Piloto and superquadras and the construction of Ceilândia), social space (social factors that influence how space is produced), and personalized space (how an individual moves within and influences a space). They show how profoundly the planned spaces of the Federal District have shaped social and personalized space. Artists often conjure the history of Brasília’s planned space to understand its present. The " 20 de 40 " video uses archival footage; the "Pequeno dicionário" video includes images of the Plano Piloto under construction; and Behr and Rodrigues refer to Brasíliàs founding fathers.

Space also mattered for the creation and dissemination of this artwork in significant ways. Behr published Brasili $A-Z$ himself, partially funding it with corporate and institutional sponsorship. He has self-published books, mainly collections of his own poetry, since the 1970s, which provides the benefit of artistic freedom, but the detriment of limited circulation. Oléria also self-produced her debut album, but she was propelled into stardom when she won the first season of Rede Globo's television show The Voice in 2012, a victory that came with a 500,000 Real cash prize, a contract with Universal Music, and a New Year's Eve performance in Copacabana, among other perks. Brazil's media giant and massive television spectatorship thus played a hand in an unlikely Cinderella story.

In contrast, Viela 17's sponsorship and listeners primarily hail from Brasília. The music video for " 20 de 40 " was funded by the Federal District government, its Fund to Support Culture, and its Ministry of Culture. In 2014, Brasília-based DJ Raffa produced Viela’s fourth album, also entitled 20 de 40. The production was slowed down when Raffa's studio, in the administrative region Riacho Fundo I, was burglarized in January 2014, a harsh example of how the violence and crime about which Viela 17 raps influences its members' lives and artistic production (Ribeiro; "Mobilização Studio Brothers").

By comparison, Nunca te vi de boa was relatively seamlessly recorded with mixer John McEntire in Chicago and produced by the British label Far Out 
Recordings. The album's multinational origin story fits the profile of the band's members, many of whom have lived abroad (Praxis). The video for "Pequeno dicionário" was financed primarily by fans, and they are listed in the credits. Rodrigues is a professor at the University of Brasília, the school where Oléria and some of Sexy Fi's members studied, and Do livro de carne was published by the well-respected Brasília publisher Thesaurus. Despite their different trajectories, the production quality (sound, layout, paper, and so forth) is extremely high on all five of the recordings and publications. These background stories accentuate how the spatial mobility of the artists has influenced and been influenced by the art they produce. Moreover, the spatial mobility of their art (What borders does it cross? How do people find it?) has been determined by various economic, technological, commercial, and aesthetic factors.

Massey calls for uprooting space from the concepts with which it automatically has been associated, such as stasis, closure, and representation. Instead she advocates for relating space to heterogeneity, relationality, and coevalness "where it releases a more challenging political landscape" (13). Brasília’s contemporary cultural texts evince the liveliness of Massey's proposal, demonstrating the variety of negotiations that have shaped and continue to shape the Federal District.

\section{Notes}

1 Support for this research was provided by two University of Minnesota awards: an Imagine Fund Award and the Office of the Vice President for Research's Grant-in-Aid of Research, Artistry and Scholarship. Special thanks to Anderson Luís Nunes da Mata, Daniela Mara, Japão, Leila Lehnen, Manoel Jevan, Nicolas Behr, and Regina Dalcastagnè for their help with this project.

2 See Evenson Two Brazilian Capitals; Paviani and Bica Brasília, ideologia e realidade; Holston The Modernist City; Gouvêa Brasília: a capital da segregação, "Habitação e emprego," Brasília: dimensões da violência urbana; El-Dahdeh Lucio Costa; Gustavo Lins Ribeiro O capital da esperança; and Béu Expresso Brasília, Os filhos dos candangos. For a catalog of Brasília’s literary texts, see Luiz Carlos Guimarães Costa História da literatura brasiliense, which includes the titles of works by 285 poets and prose writers from Brasília.

3 In an effort to disclose the transformative power of individuals' everyday practices (cooking, walking, and so on), Certeau differentiates between strategy and tactic. A tactic is an individualized, occasionally devious, appropriation of a space for one's personal benefit (graffiti being an iconic example) in contrast to more mainstream and dominant ("strategic") ways of 
ordering a space, such as the layout of streets. See sections "The tactics of practice" and "Making Do': Uses and Tactics" in The Practice of Everyday Life.

4 The Novacap website notes that trees should not be planted in public areas for the following reasons: 1) roots can disrupt utility lines and foundations; 2) branches can interfere with windows; and 3) the planting of fruit trees on residential blocks can attract bats and mosquitos, which may enter buildings.

5 The song alludes to Seu Jorge, Marcelo Yuca, and Wilson Capellette's song "A carne," made famous in the voice of Elza Soares. Its refrain - "A carne mais barata do mercado é a carne negra" - derides the continued racism in Brazil by evoking slave markets, the tradition of undervaluing Afro-Brazilians' contribution to the nation, and the commodification of AfroBrazilian culture.

6 The recent trend of rolezinhos, when peripheral urban youth mobilize via social media to gather en masse as a flash mob at shopping malls in Brazilian cities, demonstrates desires to reframe space, sentiments of exclusion from points of the city, and the scarcity of public space where youth can socialize.

7 Brasília’s hip-hop movement, centered in Ceilândia and Planaltina, became the second musical movement from the Federal District to gain national recognition, largely due to the success of rapper Genival Oliveira Gonçalves, known as GOG.

8 See Weller and Tella.

9 Similarly, GOG’s 1998 song "Brasília periferia - parte 2," which features Japão, lists dozens of names of the Federal District's favelas and impoverished administrative regions, bringing those areas to the fore.

10 The five members of Sexy Fi are Camila Zamith (vocals), João Paulo Praxis (guitar), Ivan Bicudo (guitar and keys), Diogo Saraiva (bass), and Márlon Tugdual (drums). Zamith and Praxis's previous band, Nancy, formed in 2000, was a precursor to Sexy Fi.

11 Cobogós are a Brazilian type of concrete brise soleil, lattice walls that in the superquadras provide shade, ventilation, and visual coverage of clothes drying on the line and of other household items.

12 João Almino's 2010 novel Cidade Livre offers another example of how youth culture is spatially oriented. The ten-year-old protagonist João lives in and gives tours of the satellite city Cidade Livre. His ability to orient himself provides him a sense of importance and mastery. The mysteries he fails to clarify involve locations outside of this satellite city: Amaury Village (where a drowning occurs), the religious community where Moacyr (João's adoptive father) rediscovers Lucrécia, and the Plano Piloto whose construction allows Moacyr to make a fortune via questionable business ventures. Whereas much of the philandering and deceitfulness that pervade the novel go over his head as a boy, João knows that Moacyr keeps a home in the Cidade Livre for his trysts with Lucrécia. Although Moacyr's romantic relationships befuddle João, the boy can enjoy some modicum of control by knowing where Moacyr's rendezvous take place. João's sense of self is tied to his ability to orient himself spatially.

13 The abbreviation $W$ derives from the English west. It is used in acronyms for Brasília's locales due to concern that the $O$, from the Portuguese equivalent oeste, could be mistaken for a zero.

14 Brazilian concrete poets, notably Augusto de Campos, Haroldo de Campos, and Décio Pignatari, had a predilection for lowercase Futura Bold font.

15 As Rama argues, the written word has been used to enact power and impose order in cities. Yet Rodrigues's titles draw attention to the untraditional wordlessness of the codes that order Brasilia. The poet also refers to this in the title of his 2010 poetry collection Onde as ruas não têm nome, which conjures the utopian spirit of U2's 1987 single "Where the Streets Have No Name." 
16 For more on how Brasília is elevated to the level of a literary city in the poetry of the Federal District, see Beal, "The Art of Brasília."

17 Clarice Lispector's famous crônica "Brasília: cinco dias" (1962) similarly employs experimental language (surreal imagery, unorthodox grammar, and fragmentation) to express her personal impression of the shock Brasília caused her. The continued interest in using experimental strategies to express the emotional effect of the Plano Piloto speaks to the area's continued capacity to surprise. For more on Clarice's crônica, see Beal, Brazil Under Construction 82-89.

18 For instance, Rodrigues's poem "Primeira manhã de março" includes the verse "uma vontade de poder que o poema satisfaz" (Onde as ruas 73 ).

\section{Works Cited}

Almino, João. Cidade Livre. Rio de Janeiro: São Paulo Record, 2010. Print.

Baan, Iwan. Brasília - Chandigarh: Living with Modernity. Baden, Switzerland: Lars Müller, 2010. Print.

Beal, Sophia. Brazil under Construction: Fiction and Public Works. New York: Palgrave Macmillan, 2013. Print.

_. "The Art of Brasília: Spaces, Tactics, and Walks in the Capital's Cultural Texts." Brasil/ Brazil 47 (2013): 34-64. Print.

Behr, Nicolas. BrasíliA-Z: cidade-palavra. 3rd ed. Brasília: Teixeira, 2014. Print.

Béu, Edson. Expresso Brasília: a história contada pelos candangos. Brasília: U de Brasília, 2012. Print.

—. Os filhos dos candangos: Brasília sob o olhar da periferia. Brasília: U de Brasília, 2013. Print.

Certeau, Michel de. The Practice of Everyday Life. Trans. Steven Randall. Berkeley: U of California P, 1984. Print.

Costa, Lucio. Interviewed by Juan Antonio Zapatel. Dec.1990. Vitruvius 38.1 (2009). Web. 26 June 2014.

Costa, Luiz Carlos Guimarães da. História da literatura brasiliense. Brasília: Thesaurus, 2005. Print.

Deleuze, Gilles, and Féliz Guattari. What is Philosophy? Trans. Hugh Tomlinson and Graham Burchell. New York: Columbia UP, 1994. Print.

Economist Intelligence Unit. Latin American Green City Index. Munich: Siemens, 2010. Web. 26 June 2014.

El-Dahdah, Farès. Lucio Costa: Brasília’s Superquadra. Munich and Cambridge, MA: Prestel and Harvard U, Graduate School of Design, 2005. Print.

Evenson, Norma. Two Brazilian Capitals. Architecture and Urbanism in Rio de Janeiro and Brasília. New Haven: Yale UP, 1973. Print.

GOG. "Brasília periferia-parte 2." Das trevas à luz. Zâmbia, 1998. CD.

Gouvêa, Luiz Alberto de Campos. "Habitação e emprego: uma política habitacional de interesse social." Brasília, moradia e exclusão. Ed. Aldo Paviani and Benny Schvasberg. Brasília: U de Brasília, 1996. 231-50. Print. 
_ "A violência estrutural." Brasília: dimensões da violência urbana. Ed. Aldo Paviani, Ignez Costa Barbosa Ferreira, and Frederico Flósculo Pinheiro Barreto. Brasília: U de Brasília, 2005. 341-62. Print.

—. Brasília: a capital da segregação e do controle social: uma avaliação da ação governamental na área da habitação. São Paulo: Annablume, 1995. Print.

Governo de Brasília. Companhia Urbanizadora da Nova Capital do Brasil (Novacap), n.d. Web. 20 June 2014.

Heidegger, Martin. Poetry, Language, Thought. Trans. Albert Hofstadter. New York: Harper and Row, 1971. Print.

Holston, James. The Modernist City: An Anthropological Critique of Brasília. Chicago: U of Chicago P, 1989. Print.

Lefebvre, Henri. The Production of Space. Trans. Donald Nicholson-Smith. Malden, MA: Blackwell, 1991. Print.

Lima, Irlam Rocha. "Ellen Oléria solta a voz no show de lançamento do primeiro CD, em Taguatinga." Correio Braziliense, 2 July 2009. Web. 20 June 2014.

Lispector, Clarice. "Brasília: cinco dias." A legião estrangeira: contos. Rio de Janeiro: Editora do Autor, 1964. 162-67. Print.

Massey, Doreen. For Space. London: Sage, 2005. Print.

"Mobilização Studio Brothers DJ Raffa - Equipamentos Roubados." Facebook, 9 Jan. 2014. Web. 26 June 2014.

Moslund, Sten Pultz. "The Presencing of Place in Literature: Toward an Embodied Topopoetic Mode of Reading." Geocritical Explorations: Space, Place, and Mapping in Literary and Cultural Studies. Ed. Robert T. Tally Jr. New York: Palgrave Macmillan, 2011. 29-43. Print.

Niemeyer, Oscar. "Os caminhos da arquitetura." Piracema 1 (1993). 36-40. Print.

Oléria, Ellen. "Senzala (a feira da Ceilândia)." Peça. Carne Dura, 2009. CD.

Pardue, Derek. “'Conquistando Espaço': Hip-Hop Occupations of São Paulo.” Brazilian Popular Music and Citizenship. Ed. Idelber Avelar and Christopher Dunn. Durham: Duke UP, 2011. 205-22. Print.

—. Ideologies of Marginality in Brazilian Hip Hop. New York: Palgrave Macmillan, 2008. Print.

Paviani, Aldo. Brasília: dimensões da violência urbana. Brasília: U de Brasília, 2005. Print. , and Paulo Bica, eds. Brasília, ideologia e realidade: espaço urbano em questão. São Paulo: Projeto and Conselho Nacional de Desenvolvimento Científico e Tecnológico, 1985. Print.Praxis, João Paulo. "Nancy ressuscita como Sexy Fi com novo disco e repercussão no exterior." Interviewed by Marcelo Monteiro. Globo, 19 Nov. 2012. Web. 27 June 2014.

Rama, Angel. The Lettered City. Trans. John Charles Chasteen. Durham, NC: Duke UP, 1996. Print.

Ribeiro, Gustavo Lins. O capital da esperança: a experiência dos trabalhadores na construção de Brasília. Brasília: U de Brasília, 2008. Print.

Ribeiro, Raquel Martins. "20 de 40-Viela 17 em São Sebastião: um passeio pelos 20 anos de carreira do rapper Japão." Supernova Blog, June 2014. Web. 26 June 2014.

Rodrigues, Augusto. Do livro de carne: (brasílias invisíveis). Brasília: Thesaurus, 2011. Print. - Onde as ruas não têm nome. Brasília: Thesaurus, 2010. Print.

Sexy Fi. Nunca te vi de boa. Far Out, 2012. CD. 
"Pequeno dicionário das ruas." Nunca te vi de boa. Far Out, 2012. Music Video. Dir. André Miranda, Davi Mattos, and Santiago Dellape. YouTube. 26 June 2014. Web.

Soares, Elza. "A carne." Do cóccix até o pescoço. Maianga, 2002. CD.

Soja, Edward W. Postmodern Geographies: The Reassertion of Space in Critical Social Theory. New York: Verso, 1989. Print.

Sousa, Zuleika de. Zuleikas. Instagram, 22 Aug. 2013 to 9 June 2015. Photographs. 9 June 2015. U2. "Where the Streets Have no Name." Joshua Tree. Island, 1987. CD.

Viela 17. 20 de 40. Studio Brothers, 2012. MP3.

. "20 de 40." Studio Brothers, 2012. Music Video. Dir. Leandro G. Moura, 2012. YouTube. 26 June 2014. Web.

Weller, Wivian, and Marco Aurélio Paz Tella. "Hip-Hop in São Paulo: Identity, Community Formation, and Social Action.” Brazilian Popular Music and Citizenship. Ed. Idelber Avelar and Christopher Dunn. Durham: Duke UP, 2011. 188-204. Print.

Zamith, Camila. "Entrevista: Camila Zamith, Sexy Fi." Interviewed by Marcelo Costa. Scream \& Yell 2.0, n.d. Web. 26 June 2014.

Sophia Beal is an Assistant Professor of Portuguese at the University of Minnesota. She received her doctorate from Brown University. She is the author of Brazil under Construction: Fiction and Public Works (2013) and articles on Brazilian fiction and urbanism in the Luso-Brazilian Review, Hispania, Brasil-Brazil, Estudos de Literatura Brasileira Contemporânea, and elsewhere. She co-edited Infrastructuralism, a special issue of Modern Fiction Studies (Winter 2015). 